\title{
CONTRIBUTION OF NON-TIMBER FOREST PRODUCTS (NTFPs) UTILIZATION TO THE WELL-BEING OF WOMEN: EVIDENCE FROM NIGERIA
}

\author{
Adepoju AO*, Adewale AA and Jayeola OB \\ Department of Agricultural Economics, Faculty of Agriculture, University of Ibadan, Nigeria \\ Received: 28 June 2021: Accepted: 02 October 2021
}

\begin{abstract}
This paper assessed the contribution of NTFPs to the well-being of women living in Ewekoro Local Government Area of Ogun State, Nigeria. Logistic regression and Ordered Logistic regression models were used to assess the contribution of NTFPs to the well-being of 120 women in the study area. The mean age, monthly household income, distance of homestead to forest and homestead to the nearest market were 47 years, $\$ 144.4,2.0 \mathrm{~km}$ and $1.8 \mathrm{~km}$ respectively while $70.5 \%$ of the women used NTFPs as food. The housing dimension had the highest index of 0.537 while the overall index of 0.491 indicates a moderate level of well-being for respondents. NTFPs utilization significantly increased with household income and primary occupation but decreased with increasing age, level of education, distance from homestead to forests, distance to the nearest market and access to credit. Women's well-being increased with utilization of NFTPs, being married, distance from homestead to the nearest market and access to credit but decreased with the distance of homestead to the forest, association membership and income. It is recommended that agricultural advisory and extension services in terms of NTFPs collection and utilization be provided; unconditional cash transfers and other consumption smoothening aids should be provided; necessary road networks should be rehabilitated or constructed, this will enhance NTFPs utilization; credit access should be provided for rural women, and rural women should be mobilized to form and/or join associations. Given that, NTFPs utilization contributes to the well-being of women, policies and programs that will enhance women's utilization of NTFPs should be put in place.
\end{abstract}

Keywords: Non-timber forest products, Well-being index, Utilization, Women, Logistic regression model

\section{INTRODUCTION}

Issues affecting women and their well-being have been accorded increasing attention because women are still much more likely than men to be poor (UNFPA 2010), despite many international agreements affirming their human rights. United Nations estimates indicate that up to $70 \%$ of the world's poor are women, and in developing countries they constitute the majority of the labour force, playing key roles in managing community resources and helping to improve food security and protecting the environment (UNEP 2006; UN WomenWatch 2009). Alleviating poverty and particularly that of women in the rural areas is therefore of central policy-making concern to people and governments all over the world.

*Corresponding author: abimbola.adepoju@yahoo.com
The idea of a good life makes well-being a relative concept defined according to material circumstances as well as individual preferences and social and cultural contexts. This has resulted in the shift from moneymetric measures of well-being to subjective well-being that takes into account subjective aspects such as the perception of satisfaction, happiness, security and freedom (Kingdon and Knight 2006; Costanza et al. 2007). Subjective well-being refers to the well-being as declared by the person. It can be treated as a self-reported measure of utility and has been used as "an umbrella term" which describes how people feel about their lives in the social sciences (Dolan et al. 2008; Diener et al. 1999). It is measured from a subjective wellbeing/happiness approach, which is common in the relevant literature (Rojas 2012). 
Furthermore, subjective well-being approaches have been used to measure the perceived poverty line, thus complementing or replacing income-based approaches (Kingdon and Knight 2006; Pradhan and Ravallion 2000; Rojas 2008; Guardiola and Garcia-Munoz 2012).

One way towards the enhancement of women's well-being is the utilization of forest products, which is central to poverty alleviation of rural women as forests provide products for different uses at households and industrial levels (Appiah 2009). In recent years, the role of forest resources in household economies and rural development in developing countries has received increasing attention (Angelsen et al. 2014).

A large proportion of the rural population earn their living from the collection and sales of non -timber forest products (NTFPs). They also meet some parts of their construction, storage, agricultural, energy, nutritional and medicinal needs from forests.(Agbogidi and Okonta 2003). NTFP collection and marketing is a traditional and cultural activity in many regions of the world. Currently, about $75 \%$ of poor people in the world depend on NTFPs for their subsistence while $80 \%$ of rural populations living around forests in developing countries use NTFPs daily (Noubissie et al. 2008). NTFPs have also significantly met the health and nutritional needs as well as the income of over $80 \%$ of women in the developing world (ILO 2002).

The world is grappling with a myriad of problems, including deepening poverty in many countries; especially forest-dependent communities. These communities are mostly located in remote areas where many services are limited. Consequently, these communities find themselves heavily reliant on the natural resources within their proximity. It is estimated that about 1.6 billion people worldwide depend on forests for food, fuel, shelter, and income (Ban Ki Moon, 2015). Therefore, forest resources, particularly NTFPs have been established as an essential source of livelihood for the majority of forest-dependent communities (Suleiman et al. 2017). However, despite the importance of NTFPs in sustaining livelihood and poverty, smoothening in rural communities, especially those living on the forest fringes of Nigeria, they are highly depleted and poorly conserved (Ros-Tonen 2012). Poverty is more widespread in the rural areas where the major sources of income are farming and harvesting of forest products. Many studies have focused more on the utilization of NTFPs as well as the level of participation and economic empowerment of women through NTFPs, amongst others, notable of such studies are Suleiman et al. (2017) and Adedayo et al. (2010) in Nigeria; Mainga (2016) in Nairobi; Laaribya and Alaoui (2017) in Morocco and Rahut et al. (2016) in Bhutan. However, there is a scarcity of empirical information on how NTFPs have contributed to the well-being of women in rural areas, although they are the main users of NTFPs. Thus, for a sustainable enhancement of well-being, empirical studies on the utilization of NTFPs and their contribution to the well-being of women are important contemporary policy requirements. Arising from the foregoing, the objective of this study is to examine the utilization of NTFPs and their contribution to the wellbeing of women in Ewekoro Local Government Area of Ogun State. This study has implications for change in policies directed towards enhanced well-being of women, improved conservation practices of NTFPs and community development with a view on sustainability.

\section{MATERIALS AND METHODS \\ Study area}

The study was conducted in Ewekoro Local Government Area of Ogun State. It lies between $6^{\circ} 56^{\prime} \mathrm{N}$ and $3^{\circ} 13^{\prime} \mathrm{E}$ and has a total area of 594 square kilometers. With a population of 55,156 people, indigenous dwellers of this local government area engage primarily in farming, forest management and trading activities. It is located in the moderately hot, humid tropical climatic zone of Southwestern Nigeria. There are two distinct seasons in this area: the rainy season which lasts from March/April to October/ November and the dry season which lasts for the rest of the year, October/November to 
March/April. The temperature is relatively high during the dry season, while low temperatures are experienced during the rain especially between July and August when the temperature could be as low as $24^{\circ} \mathrm{C}$. There is also an adequate arable land space that supports the production of agricultural products like sugarcane, cassava, kolanut, palm kernel, yam, cocoa, rubber, coffee and a variety of fruits and vegetables as well as fish farming, piggery, poultry and livestock production.

The study area is a settlement of fringe communities where people are allowed to freely collect NTFPs.

\section{Data collection}

For equal representation, five out of the ten wards in the study area were randomly selected at 30 respondents per ward to give a total of 150 respondents. However, one hundred and twenty (120) women gave consistent responses and were included in the analysis. The survey included questions about the socio-economic characteristics, availability and utilization of NTFPs and dimensions of well-being (health, autonomy, education and housing).

\section{Analytical techniques}

The dimensions selected for measuring household well-being were measured into different scales, as such, indices were created for each of the dimensions and these were aggregated into a composite index following the method adopted by Gautam and Anderson (2016). The numbers of indicators created for each of these were five for health, autonomy and education while housing had nine. To obtain the index for each dimension, the average of the weights of all indicators was derived. The composite well-being index was then estimated by averaging all the dimension weights. The composite well-being index ranged from 0 to 1 . A score around 0 indicates a low level of well-being while a score around the value of 1 indicates a high level of well-being.

\section{Logistic Regression Model.}

The logistic regression model was used to identify the factors influencing the utilization of NTFPs by women. The Logistic Regression Model describes the relationship between categorical response and a set of predictor variables. The categorical dependent variable can be binary, ordinal or nominal. Logit Regression is useful in that it can take input with any value from negative infinity to positive infinity. This study used a binary Logit regression model as the response variable is dichotomous. The general model is stated explicitly in equations 1 to 8 as follows:

$$
\begin{aligned}
P\left(Y_{i=m}\right) & =\frac{1}{1+e^{-z} \ldots \ldots \ldots \ldots \text { eqn } 1} \\
\frac{P}{1-P} & =e^{z} \ldots \ldots \ldots \text {......eqn } 2
\end{aligned}
$$

$P \quad$ is the probability of occurrence of the dependent variable $\mathrm{Yi}$ equal to $\mathrm{a}$ certain value,

$m, z$ is the predictor variable and can be said to be a linear combination of the $\mathrm{c}$ on version factors,

$e \quad$ is the base of natural logarithm and

$P$ is the estimated probability of occurrence of one point of the dependent variable. From eqn 2 ,

$$
1-P=1-\frac{1}{1+e^{-z}} \ldots \ldots \ldots \text { eqn } 3
$$

1-P is the probability of failure.

Given that,

$$
Y=\frac{p}{1-p} \ldots \ldots \ldots \text { eqn } 4
$$

Then,

$$
Y=e^{z}=\exp (z) \ldots \ldots \ldots \text { eqn } 5
$$

$Y=\frac{P}{1-P}$, represents the odd of the evaluative factors occurring for each explicative factor.

Assuming $\mathrm{Z}$ is a linear function of a set of predictor variables, then,

$$
\begin{aligned}
& Z=\beta_{0}+\beta_{1} X_{1 i}+\beta_{2} X_{2 i}+\beta_{3} X_{3 i} \\
& +\cdots \ldots+\beta_{n} X_{n i} \ldots \ldots \ldots \ldots \text { eqn } 6
\end{aligned}
$$


If equation (6), then;

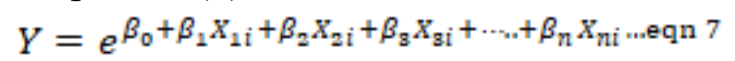

The logit regression model is given as:

$$
Y=\exp \left(\begin{array}{c}
\beta_{0}+\beta_{1} \Sigma X_{1 i}+\beta_{2} \Sigma X_{2 i} \\
+\beta_{3} \Sigma X_{3 i}+\cdots \ldots+\beta_{n} \Sigma X_{n i}
\end{array}\right) \ldots \text { eqn } 8
$$

The Ordered Logistic regression model was used to examine the effect of NTFPs utilization on the well-being of women in the study area. The model, based on a continuous latent variable was employed to investigate and determine the effect of socioeconomic variables such as education, age, marital status, income, distance to forest, distance to market, access to credit and primary occupation (definition of model variables is presented in Table 1) on the well-being of women and the impact of each variable on the likelihood of individuals to be placed in one of the three well-being groups which are high, medium and low. The Ordered Logistic Regression model is stated explicitly as follows:

$$
y_{i}^{*}=\beta_{1} X_{i}+\varepsilon_{i} \quad \infty<y_{i}<-\infty \quad \ldots \text { eqn } 9
$$

where

$y_{i}^{*}$ : well-being group/category (low, medium, high)

$\beta_{1}$ : Vector of parameters to be estimated

$X_{i}$ : Observed vector of non-random explanatory variable which shows the characteristic of $\mathrm{i}^{\text {th }}$ person

$\varepsilon_{\mathrm{i}}$ :Residual error which is logistically distributed.

Since $y_{i}^{*}$ is a latent variable, standard regression techniques are not applicable to estimate the sample size.

If $y_{i}$ is considered as a discrete and observable variable which shows different levels of people's well-being, the relation between latent variable $\mathrm{y}_{\mathrm{i}}{ }^{*}$ and observable variable $\mathrm{y}_{\mathrm{i}}$ is obtained from ordered Logit model as follows:

$$
\begin{aligned}
& y_{i}=1 \text { if }-\infty \leq y_{i}^{*}<\mu_{1}, \\
& i=1 \ldots n \ldots \text { eqn } 10 \\
& y_{i}=2 \text { if }-\infty \leq y_{i}^{*}<\mu_{2}, \\
& i=1 \ldots n \ldots \text { eqn } 11 \\
& y_{i}=3 \text { if }-\infty \leq y_{i}^{*}<\mu_{3}, \\
& i=1 \ldots n \ldots \text { eqn } 12 \\
& y_{i}=J \text { if } \mu_{J-1} \leq y_{i}^{*}<+\infty, \\
& i=1 \ldots n \ldots \text { eqn } 13
\end{aligned}
$$

In which " $n$ " is the value for the sample size, " $\mu$ " and "s" are the thresholds that define observed discrete answers and should be estimated.

The probability of $y_{i}=J$ should be calculated by the following relation:

$$
\begin{gathered}
\operatorname{Pr}\left(y_{i}=J\right)=\operatorname{Pr}\left(y_{i} \geq \mu_{J-1}\right)= \\
\operatorname{Pr}\left(\varepsilon_{i} \geq \mu_{n-1}-\beta X_{i}\right)=F\left(\beta X_{i}-\mu_{J-1}\right) \ldots \text { eqn } 14
\end{gathered}
$$

However, while most studies have attempted to link the contribution of NTFPs' utilization to the well-being of farmers, this study is unique in that it provides a link between the availability and utilization of NTFPs and the four dimensions of the well-being of women in Ewekoro LGA, Nigeria.

\section{RESULTS AND DISCUSSION \\ Socio-economic characteristics of respondents}

Table 2 presents the socio-economic characteristics of the respondents. The majority of the women were between 40 and 49 years while only $9.2 \%$ were above 60 years. However, the mean age was $47 \pm 11.1$ years. More than four-fifths $(80.8 \%)$ of the respondents were married and $77.5 \%$ of the respondents had at least one form of formal education or the other since only about onefifths had no formal education. The mean household size was approximately $6 \pm 1$ members with $69.2 \%$ having between 6 and 
Table 2: Socio-economic characteristics of the respondents

\begin{tabular}{|c|c|c|c|c|}
\hline Variable & Frequency & Percentage & Mean & Std. Dev. \\
\hline $\begin{array}{l}\text { Age } \\
0-29 \\
30-39 \\
40-49 \\
50-59 \\
>60\end{array}$ & $\begin{array}{l}21 \\
33 \\
35 \\
20 \\
11\end{array}$ & $\begin{array}{r}17.5 \\
27.5 \\
29.2 \\
16.7 \\
9.2\end{array}$ & 47.0 & 11.1 \\
\hline $\begin{array}{l}\text { Marital status } \\
\text { Single } \\
\text { Married } \\
\text { Divorced/Separated } \\
\text { Widowed }\end{array}$ & $\begin{array}{c}2 \\
97 \\
14 \\
7\end{array}$ & $\begin{array}{c}11.7 \\
80.8 \\
11.7 \\
5.8\end{array}$ & & \\
\hline $\begin{array}{l}\text { Educational status } \\
\text { No formal Education } \\
\text { Primary } \\
\text { Secondary } \\
\text { Tertiary } \\
\end{array}$ & $\begin{array}{l}27 \\
50 \\
25 \\
18\end{array}$ & $\begin{array}{l}22.5 \\
41.7 \\
20.8 \\
15.0\end{array}$ & & \\
\hline $\begin{array}{l}\text { Household size (number) } \\
1-5 \\
6-10\end{array}$ & $\begin{array}{l}37 \\
83 \\
\end{array}$ & $\begin{array}{r}30.8 \\
69.2 \\
\end{array}$ & 6.0 & 1.0 \\
\hline $\begin{array}{l}\text { Primary occupation } \\
\text { Farming } \\
\text { Trading } \\
\text { Artisan } \\
\text { Private business } \\
\text { Government Job }\end{array}$ & $\begin{array}{c}50 \\
31 \\
3 \\
22 \\
14\end{array}$ & $\begin{array}{c}41.7 \\
25.8 \\
2.5 \\
18.3 \\
11.7\end{array}$ & & \\
\hline $\begin{array}{l}\text { Access to credit } \\
\text { Yes } \\
\text { No }\end{array}$ & $\begin{array}{l}71 \\
49\end{array}$ & $\begin{array}{l}59.2 \\
40.8\end{array}$ & & \\
\hline $\begin{array}{l}\text { Source of credit } \\
\text { Friends/ Relatives } \\
\text { Cooperatives } \\
\text { Money Lenders } \\
\text { Microfinance Banks }\end{array}$ & $\begin{array}{r}19 \\
33 \\
1 \\
18\end{array}$ & $\begin{array}{r}26.8 \\
46.5 \\
1.4 \\
25.4\end{array}$ & & \\
\hline $\begin{array}{l}\text { Association Membership } \\
\text { Yes } \\
\text { No }\end{array}$ & $\begin{array}{l}94 \\
26\end{array}$ & $\begin{array}{l}78.3 \\
21.7\end{array}$ & & \\
\hline $\begin{array}{l}\text { Type of Association } \\
\text { Cooperatives } \\
\text { Religious Groups } \\
\text { Occupational groups } \\
\text { Cultural Groups } \\
\text { Gender-based organizations }\end{array}$ & $\begin{array}{r}23 \\
29 \\
36 \\
4 \\
2\end{array}$ & $\begin{array}{r}24.5 \\
30.9 \\
38.3 \\
4.3 \\
2.1\end{array}$ & & \\
\hline
\end{tabular}




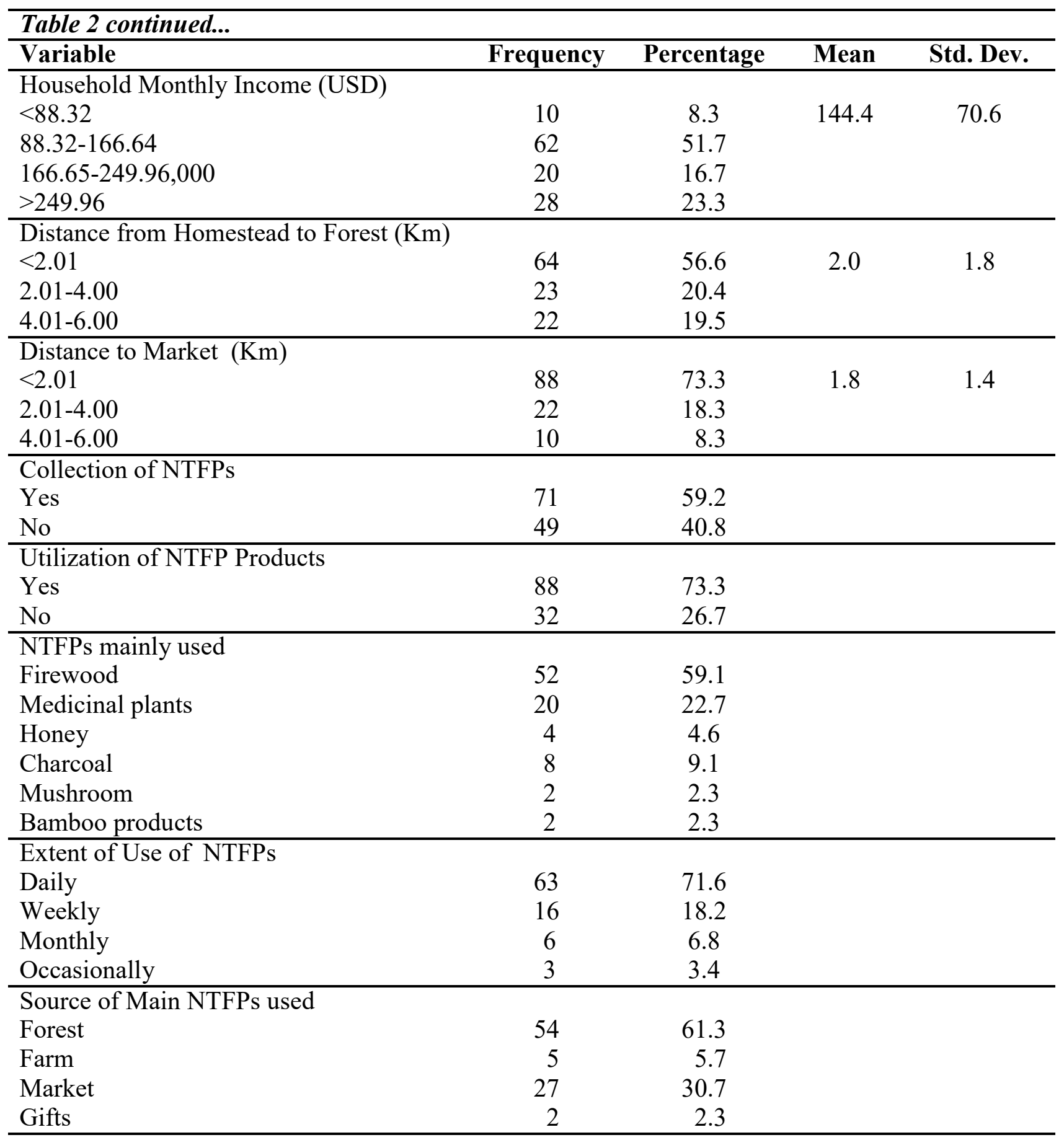

Source: Field Survey

10 members per household.

In terms of occupation, $41.7 \%$ were primarily engaged in farming while $59.2 \%$ had access to credit and the main sources of credit were cooperatives, friends/relatives and microfinance banks. In addition, $78.3 \%$ of the respondents belonged to an association that included occupational groups, religious groups, cooperatives, cultural groups and gender-based organizations. The mean monthly household income was $\$ 144.49 \pm 70.6$ while $51.7 \%$ reported monthly incomes between $\$ 83.32$ and $\$ 166.64$. The mean distance from homestead to the forest and from homestead to the nearest market were $2.0 \mathrm{~km} \pm 1.8$ and $1.8 \mathrm{~km} \pm 1.4$ respectively. About three-fifths (59.2\%) of the respondents 
collected NTFPs while $73.3 \%$ used the products collected. The NTFPs mainly used were firewood, medicinal plants, charcoal, honey, mushroom and bamboo products. In terms of the extent of use, $71.6 \%$ used NTFPs daily, while the main sources of NTFPs used were from forests and markets followed by the farm and gifts.

The common NTFPs used as food were fruits, walnut, bitter leaf, scent leaf, bushmeat, snails, mushroom, ginger, honey, waterleaf, Thaumatococcus danielli,
Megaphrynium macrostachyum_while bitter leaf, bitter kola, ginger, honey, roots, seeds, resins and barks of trees were commonly used as medicine. Bamboo and Raffia palms were commonly used for crafts/construction while firewood, charcoal, honey, bushmeat, bamboo products, herbs were sold.

NTFPs were mainly used as food $(70.5 \%)$, medicine $(22.7 \%)$, crafts/construction material $(3.4 \%)$ and sold for income $(3.4 \%)$. This finding conforms to the findings of Arnold and Townson (1998) and Reddy and

Table 3: Well-being capability index to the elementary subsets (indicators)

\begin{tabular}{|c|c|c|c|}
\hline Dimension & Indicator & $\begin{array}{l}\text { Index Per } \\
\text { Indicator }\end{array}$ & $\begin{array}{l}\text { Index Per } \\
\text { Dimension }\end{array}$ \\
\hline $\begin{array}{l}\text { Health } \\
\left(\mu_{1}\right)\end{array}$ & $\begin{array}{l}\mu_{11} \text { Type of illness suffered in the last year } \\
\mu_{12} \text { Use of health facility by household members } \\
\mu_{13} \text { Type of facility consulted by household } \\
\mu_{14} \text { Suffered injury in the last year } \\
\mu_{15} \text { Level of satisfaction }\end{array}$ & $\begin{array}{l}0.2892 \\
0.9083 \\
0.3569 \\
0.675 \\
0.3304\end{array}$ & \\
\hline $\begin{array}{l}\text { Housing } \\
\left(\mu_{2}\right)\end{array}$ & $\begin{array}{l}\mu_{21} \text { Dwelling ownership } \\
\mu_{22} \text { Type of housing unit } \\
\mu_{23} \text { Quality of construction material } \\
\mu_{24} \text { Wall of house plastered } \\
\mu_{25} \text { Type of toilet facility } \\
\mu_{26} \text { Source of drinking water } \\
\mu_{27} \text { Connection to the national grid for electricity } \\
\mu_{28} \text { Refuse disposal } \\
\mu_{29} \text { Level of satisfaction }\end{array}$ & $\begin{array}{l}0.3667 \\
0.7667 \\
0.5680 \\
0.8083 \\
0.3410 \\
0.6250 \\
0.7250 \\
0.3313 \\
0.3150\end{array}$ & 0.5116 \\
\hline $\begin{array}{l}\text { Education } \\
\left(\mu_{3}\right)\end{array}$ & $\begin{array}{l}\mu_{31} \text { Primary school in the community } \\
\mu_{32} \text { Secondary school in the community } \\
\mu_{33} \text { Presence of qualified teachers } \\
\mu_{34} \text { Good condition of school facilities } \\
\mu_{35} \text { Level of satisfaction }\end{array}$ & $\begin{array}{l}0.9000 \\
0.5667 \\
0.6083 \\
0.3637 \\
0.2221 \\
\end{array}$ & 0.5373 \\
\hline $\begin{array}{l}\text { Autonomy } \\
\left(\mu_{4}\right)\end{array}$ & $\begin{array}{l}\mu_{41} \text { Decision on obtaining healthcare for household } \\
\mu_{42} \text { Personal savings } \\
\mu_{43} \text { Decision on birth control } \\
\mu_{44} \text { Dependence on spouse } \\
\mu_{45} \text { Level of satisfaction }\end{array}$ & $\begin{array}{l}0.3167 \\
0.9083 \\
0.2704 \\
0.1008 \\
0.3192\end{array}$ & 0.5328 \\
\hline $\begin{array}{l}\text { Composite } \\
\text { index }\end{array}$ & & & $\begin{array}{l}0.3862 \\
0.4913\end{array}$ \\
\hline
\end{tabular}

Source: Field Survey 
Chakravarty (1999) which noted that forest products and the income generated from them can be quite significant in alleviating the high level of food security of local communities and throughout the developing world.

\section{Well-being capability index}

The well-being index estimation (Table 3) showed that the housing dimension had the highest score of 0.537 , followed by education (0.552) and health (0.511). The dimension with the lowest score was autonomy with a score of 0.386 . The overall well-being index for this study of 0.491 implies that the women in the study area have a moderate level of well-being. This overall index is lower than the National Human Development Index (HDI) of 0.532 (UNDP 2018).

This is expected because the index for this study was estimated only for women in one Local Government Area while the HDI was for the whole country. The HDI is a composite measure of well-being that used three dimensions of health, education and income, while this study used an index with four dimensions - health, education, housing and autonomy. Majumder (2009) in analyzing the well-being of Indian women over two periods estimated well-being values of 0.606 and 0.649 for the data set of 1998/1999 and $2005 / 2006$ respectively. The values are much higher than that estimated for this study as expected since the study concentrated on Indian women in both urban and rural in contrast to this study which focused on women in rural Nigeria.

\section{Factors influencing the utilization of NTFPs}

The factors influencing NTFPs utilization is presented in Table 4. Significant factors influencing the utilization NTFPs by women in the study area were age, level of education, primary occupation, the distance of homestead to the forest, distance of homestead to market and household income.

The utilization of NTFPs decreased significantly with age, level of education, distance to forest and distance to market. The negative relationship between age, distance to forest and distance to market with the utilization of NTFPs is consistent with the

Table 4: Factors influencing non-timber forest products utilization

\begin{tabular}{lllr}
\hline Variables & Coefficients & \multicolumn{1}{l}{ Z } & dy/dx \\
\hline Age of respondent & $-0.563^{* *}$ & -1.98 & -0.059 \\
Level of Education & $-0.407^{* * *}$ & -3.43 & -0.042 \\
Primary Occupation & $1.240^{*}$ & 1.73 & 0.142 \\
Marital Status & 0.191 & 0.17 & 0.021 \\
Household Size & -0.137 & -0.42 & -0.014 \\
Distance of Homestead to Forest & $-0.414^{* * *}$ & -3.48 & -0.043 \\
Distance of Homestead to nearest market & $-0.554^{* *}$ & -1.95 & -0.058 \\
Access to credit & -0.246 & -0.31 & -0.025 \\
Association Membership & 0.002 & 0.00 & 0.000 \\
Household income & $0.220^{* * *}$ & 3.60 & 0.047 \\
Constant & 9.422 & 1.25 & \\
Prob> chi & 0.000 & & \\
Log likelihood & -35.23 & & \\
Number of observations & 120 & & \\
LR chi ${ }^{2}(\mathbf{1 0})$ & 68.71 & & \\
Pseudo R & 0.494 & & \\
\hline
\end{tabular}

Source: Logistic Regression Analysis Result

Note: $*, * *$ and $* * *$ represent significance level at $10 \%, 5 \%$ and $1 \%$ respectively 
findings of Suleiman et al. (2017) where the tendency to engage in NTFPs reduced with age and households living further away from market were less likely to collect NTFPs for household consumption and sales for cash income generation. However, the negative association between level of education and utilization of NTFPs is consistent with the finding of Shemnga (2015) in which utilization of NTFPs reduced with increasing formal education.

However, utilization of NTFPs increased significantly with being engaged in farming which follows after the finding of Suleiman et al (2017). NTFPs utilization was also positively related to household income and is consistent with the findings of Ogundele et al. (2012) where utilization of NTFPs improved income generated from the sales of fuel wood, fruits, vegetables, bush meat marketing and other forest-based activities.

The marginal effects results show that a year increase in age reduced the likelihood of the use of NTFPs by $5.6 \%$. This is consistent with the findings of Mulenga et al. (2012) and Suleiman et al. (2017) which reported inverse relationships between age and NTFPs utilization. As such, as women grow older, their likelihood of utilization of NTFPs declines. Similarly, with respect to the level of education, a change in formal education decreased the likelihood of utilizing NTFPs by $4.1 \%$. That is, women's utilization of NTFPs reduced with an increase in the level of formal education. Also, a kilometer change in the distance from homestead to the forest and nearest market decreased the utilization of NTFPs by $4.1 \%$ and $5.5 \%$ respectively. This could be due to the drudgery and costs associated with walking long distances to the forest and transporting the NTFPs from the forest to the homestead and from the homestead to the market. This usually promotes the use of nearby alternatives (Suleiman et al. 2017; Raufu et al. 2012; Opaluwa et al. 2011).

On the other hand, being a farmer, increased the likelihood of utilization of NTFPs by $12.4 \%$. This is expected as NTFPs are readily

Table 5: Effect of non-timber forest products utilization on the well-being of women

\begin{tabular}{llll}
\hline Variables & Coefficients & Standard Error & Z \\
\hline Age of respondents & -0.033 & 0.024 & -1.35 \\
Level of Education & -0.049 & 0.064 & -0.04 \\
Primary Occupation & -0.516 & 0.446 & -1.16 \\
Marital Status & $2.618^{* * *}$ & 0.784 & 3.34 \\
Household Size & -0.013 & 0.205 & -0.06 \\
Distance to Forest & $-0.041^{* * *}$ & 0.133 & -3.09 \\
Distance to nearest market & $0.305^{*}$ & 0.179 & 1.70 \\
Access to credit & $1.085^{* *}$ & 0.550 & 1.98 \\
Association Membership & $-1.697^{* *}$ & 0.662 & -2.56 \\
NFTPs Utilization & $1.539^{* * *}$ & 0.587 & 2.62 \\
Household income & $-1.171^{* *}$ & 0.497 & 2.36 \\
Cut 1 & -15.942 & 5.568 & \\
Cut 2 & -10.907 & 5.366 & \\
Prob> chi & 0.000 & & \\
Log likelihood & -75.813 & & \\
Number of observations & 120 & & \\
LR chi ${ }^{2}(\mathbf{1 0})$ & 66.72 & & \\
Pseudo R & 0.306 & & \\
\hline
\end{tabular}

Source: Ordered Logistic Regression Analysis Result

Note: $*, * *$ and $* * *$ represent significance level at $10 \%, 5 \%$ and $1 \%$ respectively 
available in farms and forests, thus making it easier for farmers to use more of NTFPs and sell some (Moubarakatou 2017; Suleiman et al. 2017).

A unit change in household income increased the utilization of NTFPs by $22.0 \%$, which implies increased purchasing power and level of NTFPs utilization by $22.0 \%$. This finding supports the findings of Ogundele et al. (2012) in which collection and sales of NTFPs improved income.

\section{Effect of NTFPs utilization on the well-} being of women

To evaluate the effect of NTFPs utilization on the well-being of women, the well-being index was categorized into three groups: low $(<0.4914)$, medium $(0.4914-0.6127)$ and high $(>0.6127)$. All the women had a wellbeing index between 0 and 1 and each was categorized into one of these three groups. The results are presented in Tables 5 and 6 .

NTFPs utilization had a positive effect on the level of well-being of women, this implies that the use of NTFP improved well-being. Since NTFPs utilization contributes positively to health, nutrition and level of income, the level of well-being of women who utilize these products in different ways is expected to be higher than that of those who do not use them (Suleiman et al., 2017).

Marital status also positively influenced the level of well-being, which implies that being married improved the level of well-being. This finding agrees with the findings of Liang and Shen (2016) in which married respondents reported higher well-being than single respondents. However, this contradicts the findings of Olowe et al. (2014) in which married respondents had a lower well-being index when compared to the divorced or single respondents.

Access to the credit also had a positive effect on the level of well-being as expected. This is expected because accessibility to credit would enable the women to increase the scale of their business and improve livelihoods and cause an increase in income level. Furthermore, the distance of homestead to nearest market also had a positive effect on well-being, this contrasts with the findings of Suleiman et al. (2017) where an inverse relationship was reported.

The negative effect of association membership on the level of well-being contrasts with the findings of Olowe et al. (2014) in which membership in groups with a high diversity of members improved wellbeing. Being a member of one or more groups

Table 6: Marginal effect of NTFPs utilization on well-being of women

\begin{tabular}{llll}
\hline Variables & High & Medium & Low \\
\hline Age of respondent & 0.008 & 0.002 & 0.000 \\
Level of Education & 0.012 & 0.004 & 0.000 \\
Primary Occupation & 0.128 & 0.038 & 0.006 \\
Marital Status & $-0.560^{* * *}$ & $0.371^{* *}$ & -0.093 \\
Household Size & 0.003 & 0.000 & 0.000 \\
Distance to Forest & $-0.102^{* * *}$ & $-0.030^{* *}$ & $0.004^{*}$ \\
Distance to nearest market & $-0.075^{*}$ & 0.179 & 0.003 \\
Access to credit & $0.265^{* *}$ & $0.088^{*}$ & $-0.022^{*}$ \\
Association Membership & $-1.697^{* *}$ & $0.091^{* * *}$ & -0.014 \\
NFTPs Utilization & $1.539^{* * *}$ & 0.587 & $-0.310^{* * *}$ \\
Household income & $0.291^{* *}$ & $0.086^{* *}$ & $-0.474^{* * *}$ \\
\hline
\end{tabular}

Source: Ordered Logistic Regression Analysis Result

Note: $* * *$ and $* * *$ represent significance level at $10 \%, 5 \%$ and $1 \%$ respectively 
or associations especially cooperatives and occupational groups should ordinarily increase the accessibility to credit and vital information for improved well-being.

In addition, income had a negative effect on well-being, this implies that as income increased, the level of well-being decreased. This contradicts the work of Knight et al. (2009) which noted that relative income influenced happiness which was used as a proxy for well-being. It also contradicts the work of Cheryl (2014) whose study revealed that income positively influenced well-being and explained about $95.5 \%$ of the variation in well-being. Furthermore, the distance of the homestead to the forest also had a negative effect on well-being. This contrasts the direct relationship as reported by Suleiman et al. (2017).

The marginal effects for the three well-being categories on women's NTFPs utilization are presented in Table 6. Accordingly, utilization of NTFPs increased the probability of reporting high and medium well-being by $34.5 \%$ and $11.9 \%$ respectively while it decreased the probability of reporting low well-being by $31.0 \%$.

Being married decreased the probability of reporting high well-being by $56.0 \%$ while it increased the probability of reporting a medium level of well-being by $37.1 \%$. An additional increase in the distance to the forest decreased the probability of reporting high and moderate well-being by $10.2 \%$ and $3.0 \%$ respectively while it increased the likelihood of reporting low well-being by $0.4 \%$. Also, an additional increase in the distance to the nearest market decreased the probability of reporting high well-being by $7.5 \%$ and the probability of reporting medium well-being by $2.2 \%$.

Accessibility to credit increased the probability of reporting high well-being by $26.5 \%$, medium well-being by $8.8 \%$ and reduced the probability of low well-being by $22.1 \%$. Further, association membership increased the probability of reporting medium and high well-being by $9.1 \%$ and $35.2 \%$ respectively while income increased the probability of reporting a high and medium level of well-being increased by $29.1 \%$ and $8.6 \%$ respectively while the probability of reporting low well-being decreased by $47.4 \%$ as income increased.

\section{CONCLUSION}

The involvement of women in NTFPs activities cannot be undermined given the fact that such activities are women inclined and a major propelling factor in the level of collection and utilization which play a significant role in their well-being.

It is recommended that agricultural advisory and extension services in terms of NTFPs collection and utilization be extended to rural women as engagement in agriculture was positively significant to its utilization, also in order to make farming attractive as a primary occupation, policies and programs that will enhance women's participation in farm and off-farm activities should be made; also since income positively influenced NTFPs utilization, cash transfers and other consumption smoothening aids should be provided to rural women as this will enhance their utilization of NTFPs. Also necessary road networks that will facilitate access to forests as well as to market should be rehabilitated or constructed, this will enhance NTFPs utilization.

Also since NTFPs utilization significantly affected well-being, extension services should be provided to rural women on its effective utilization; developing optimal road networks that link rural communities to the nearest markets and forests should be done, this will facilitate transportation of NTFPs from forests to these markets and enhance well-being; credit access should be facilitated for rural women, this will serve to expand their capital and enhance well-being, thus to improve access to credit, loans should be made available to women by banks and cooperatives; rural women should be mobilized to form and/or join associations, as this will enhance their well-being through information-sharing, resource-pooling and cooperatives' formation. Given that, NTFPs 
utilization contributes to the well-being of women, policies and programs that will enhance women's utilization of NTFPs should be put in place.

\section{AUTHOR CONTRIBUTION}

AAO and JOB designed the study. AAO, AAA and JOB designed the materials and methods. AAO, AAA and JOB developed the paper from inputs from all authors. AAO and JOB designed the survey instrument, collected and analysed the data. AAO and AAA discussed the results and commented on the manuscript.

\section{REFERENCES}

Adedayo A Oyun MB and Kadeba O.2010 Access of rural women to forest resources and its impact on rural household welfare in North Central Nigeria. Forest Policy and economics, 12(6), 439-450. <https.// doi:10.1016/ j.forpol.2010.04.001>

Agbogidi OM and Okonta BC 2003 Role of women in community forestry and environmental

conservation,Proceedings of the 29th Annual Conference of the Forestry Association of Nigeria (FAN) held in Calabar (pp 159-165) \

Angelsen A, Jagger P, Babigumira R, Belcher B, Hogarth NJ andBauch S 2014 Environmental income and rural livelihoods: a global-comparative analysis. World Development 64:12-28

Appiah DO 2009 Personifying sustainable rural livelihoods in forest fringe communities in Ghana: a historic rhetoric? Journal of Food, Agriculture and Environment Vol.7 (3\&4) : 873-877

Arnold M. and Townson I 1998 Assessing the potential of forest product activities to contribute to rural incomes in Africa. ODI Natural Resource Perspectives No.37. Overseas Development Institute, London, UK.

Ban Ki Moon 2015 UN secretary-general message for the international day of forests, Available online from $<$ http:// www.un.org/en/events/forestsday/2015/ sgmessage. shtml $>$.1

Cheryl TL 2014 Well-being and its determinants - case of Malaysia. BSc thesis, Taylor's University, Malaysia. $<$ https.//doi:10.13140/2.1.2585.8568 $>$

Costanza R, Fisher, B, Ali, S. Beer, C. Bond, L, Boumans, R, Danigelis J, Dickinson N, Elliott C, Farley J, Gayer D, Glenn L, Hudspeth T, Mahoney D, McCahill L, McIntoshB, Reed B, Rizvi S, Rizzo D, Simpatico T and Snapp R2007 Quality of life: an approach integrating opportunities, human needs, and subjective wellbeing. Ecological Economics, vol. 61, issue 2-3, 267-276

Diener E, Suh EM, Lucas RE and Smith H 1999 Subjective wellbeing: three decades of progress. Psychological Bulletin 125: 276-302.

Dolan P, Peasgood T and White M 2008 Do we really know what makes us happy? A review of the economic literature on the factors associated with subjective well-being. Journal of Economic Psychology 29: 94-122.

GautamY and Andersen P 2016 Rural livelihood diversification and household well-being: Insights from Humla, Nepal. Journal of Rural Studies 44:239249.

Guardiola J and Garcia-Munoz T 2012 Subjective well-being and basic needs: Evidence from rural Guatemala. Retrieved from file://C:/Users/adepo/ Downloads/Dialnet-

SubjectiveWellBeingAndBasicNeeds2942144\%20(1).pdf

History of Ewekoro Local Government Area. (n.d). Retrieved from http:// ewekorolga.og.gov.ng/history.html

International Labour Organization 2002 Women and men in the informal economy: A statistical picture, Employment Sector, International Labour Office, Geneva, Switzerland.

Kingdon G and Knight J 2006 Subjective well -being poverty vs Income poverty and capabilities poverty? Journal of Development Studies, 42(7), 11991224.

Knight J, Song L and Gunatilaka R 2009 Subjective well-being and its determinants in rural China. China Economic Review, 20, issue 4, p. 635- 
649, https://EconPapers.repec.org/ RePEc:eee:chieco:v:20:y:2009:i:4:p:63 5-649.

Laaribya S and Alaoui A 2017 Rural women and the forest issues preservation - Case study, Morocco. Biological Diversity and Conservation. 10 (2), 08-15.

Liang Y and Shen J 2016 Subjective wellbeing and its determinants in China: An empirical study based on survey data. Macrothink Institute, Research in Applied Economics, 8(3), 1-18. http:// dx.doi.org/10.5296/rae.v8i3.9806

Mainga VN 2016 Assessment of diversity and role of non-timber forest products in the livelihoods of rural communities in Kibauni Hills Forest, Machakos County.Department of Geography and Environmental studies, University of Nairobi, Kenya.

Majumder A 2009 Capability and women's well-being in India: An empirical study based on national family health survey2\&3. Paper presented at the $18^{\text {th }}$ Annual Meeting of the IAFFE, June 26-28, Boston, USA. Retrieved from http:// amlan.co.in/wp-content/ uploads/2018/05/Amlan-Paper-IAFFE2009-amlan.co_.in_.pdf.

Moubarakatou T 2017 Factors affecting household participation in non-timber forest products market in Eastern Uganda, MSc thesis, University of Nairobi, Kenya. Retrieved from http:// erepository.uonbi.ac.ke/bitstream/ handle/11295/101407/Moubarakatou\% 20 Factors $\% 20$ Affecting\% 20Household $\% 20$ Participation $\% 20 \operatorname{In} \%$ 20Non-Timber $\% 20$ Forest $\%$ 20Products $\% 20$ Market $\% 20 \mathrm{In} \%$ 20Eastern\%20Uganda.pdf? sequence $=1$ \&isAllowed $=\mathrm{y}$

Mulenga B, Richardson R and Tembo G 2012 Non-timber forest products and rural poverty alleviation in Zambia, Working Paper No. 62. Indaba Agricultural Policy Research Institute (IAPRI) Lusaka, Zambia Retrieved from http:// www.aec.msu.edu/fs2/zambia/ index.html

Noubissie ET, Chupezi J, and Ndoye O 2008
Studies on the socio-economic analysis of non-timber forest products in Africa. Synthesis of reports of studies in the project GCP/RAF/398/GER, Yaounde, Cameroun, FAO GCP/RAF/398/GER Enhancing Food Security in Central African through the management and sustainable use of NWFP: p.43.

Ogundele FO, Utin EA, Iwara AI, Njar GN and Deekor TN 2012 An assessment of non-timber forest products utilization on rural livleihoods in Ini local government area of Akwa-Ibom State, Nigeria. Journal of Biological and Environmental Science 2(8):1-13.

Olowe OO, Okunmadewa F, Yusuf S and Oni O 2014 Effect of social capital on wellbeing of rural households in Southwest Nigeria. Journal of Agriculture and Veterinary Science, 7(12):13-21

Opaluwa H I, Onuche U and Sale FA 2011 Factors affecting the collection and utilization of non- timber forest products in rural communities of North Central, Nigeria. Journal of Agriculture and Food Technology1(5):47-49

Pradhan M and Ravallion M 2000 Measuring Poverty Using Qualitative Perceptions of Consumption Adequacy.The Review of Economics and Statistics, 82(3), 462471.

Rahut D B, Behera B and Ali A 2016 Do forest resources help increase rural household income and alleviate rural poverty? Empirical evidence from Bhutan. Forests, Trees and Livelihoods, 25(3), 187-198. doi:10.1080/14728028.2016.1162754

Raufu MO, Akinniran TN, Olawuyi SO and Akinpelu MO 2012 Economic analysis of rural women income from non-timber forest products in Ife South local government area of Osun State, Nigeria. Global Journal of Science Frontier Research Agriculture and Biology 12 (1): 23-32

Reddy SR and Chakravarty SP 1999 Forest dependence and income distribution in a subsistence economy: evidence from India. World Development 27 (7), 1141 -1149 .

Rojas M 2008 Experienced Poverty and 
Income Poverty in Mexico: A Subjective Well- Being Approach. World Development, 36(6), 10781093.

Rojas M 2012 Happiness in Mexico: The importance of human relations. In $\mathrm{H}$. Selin \& G. Davey (Eds.), Happiness across cultures: Views of happiness and quality of life in non-western cultures (pp. 241-252).Dordrecht: Springer.

Ros-Tonen MA 2012 The role of non-timber forest products in sustainable tropical forest management. European Journal of Wood and Wood Products, 58(3),196201.

Suleiman MS, WasongaVO, Mbau JS, Suleiman A and Elhadi YA 2017 Nontimber forest products and their contribution to households' income around Falgore Game Reserve in Kano, Nigeria. Ecological Processes, 6:23. doi:10.1186/s13717-017-0090-8

Shemnga T 2015 Assessment of the contribution of non-timber forest products to household food security and income around Baga catchment forest in Lushoto district, Tanzania. http:// www.suaire.sua.ac.tz/bitstream/ handle/123456789/1317/TWAHA\% 20ABEID\%20SHEMNGA.pdf? sequence $=1 \&$ isAllowed $=y$

United Nations Development Programme 2018 Human development indices and indicators, 2018 statistical update. http:// hdr.undp.org/en/content/humandevelopment-indices-indicators-2018statistical-update\#:

United Nations Environment Programme 2006 Women and environmental conservation. Report by the UNEP, Division of Policy Development and Law, Nairobi, Kenya, pp. 2-24.

United Nations Population Fund 2010 Gender equality: Empowering women. http:// www.un fpa.org/gender/ empowerment.htm.

United Nations WomenWatch 2009 Women, Gender Equality and Climate Change Fact sheet. http://www.un.org/ womenwatch/feature/climate_change/ 